\title{
Growth response and tibia bone characteristics in broilers fed diets containing kaolin, bentonite and zeolite
}

\author{
M. Safaeikatouli ${ }^{1}$, F. Boldaji, B. Dastar and S. Hassani \\ Faculty of Animal Science, Gorgan University of Agricultural Sciences and Natural Resources \\ 49165-386 Gorgan, Iran
}

(Received 17 March 2011; revised version 20 February 2012; accepted 18 June 2012)

\begin{abstract}
This study was conducted to evaluate the effectiveness of adding silicate mineral in feed on tibia bone characteristics and tibia, meat, as well as on faecal ash content in broilers. Four hundred and forty eight one-day-old broiler chicks were reared using a completely randomized design with seven treatments (diets containing $0,1.5$, or $3 \%$ of kaolin, bentonite, or zeolite) having four replicates of 16 birds each for 42 days. Body weight gain was significantly $(\mathrm{P}<0.05)$ increased in treatments with $3 \%$ kaolin and two levels of zeolite (1.5 and 3\%) compared with $1.5 \%$ bentonite and control. Feed intake was significantly $(\mathrm{P}<0.05)$ higher in the treatment containing $3 \%$ bentonite compared with the treatments with $1.5 \%$ bentonite, $3 \%$ kaolin, and control. The feed conversion ratio was significantly better $(\mathrm{P}<0.05)$ in the treatment with $3 \%$ kaolin compared with $3 \%$ bentonite and control. Thickness of the wall in all treatments, except treatments with $1.5 \%$ kaolin and bentonite increased significantly when compared with the control $(\mathrm{P}<0.05)$. Treatments containing $3 \%$ bentonite or zeolite significantly improved the tibiotarsal wt/length index, robusticity index, and tibiotarsal index $(\mathrm{P}<0.05)$ when compared with the control. Tibia and meat ash as well as tibia and blood calcium contents increased significantly in treatments with $3 \%$ zeolite compared with the control $(\mathrm{P}<0.05)$. Also, the faecal ash content in the treatment with $3 \%$ zeolite decreased significantly compared with the control $(\mathrm{P}<0.05)$. Faecal dry mater in treatments with $1.5 \%$ kaolin, $3 \%$ bentonite or zeolite was significantly $(\mathrm{P}<0.05)$ higher than in the control. There were no significant $(\mathrm{P}>0.05)$ differences in tibia length, diaphysis diameter, medullary canal diameter, relative bone weight, tibia and meat dry mater, blood phosphorus, and tibia phosphorus among dietary treatments and control. In conclusion it seems that inclusion of a higher level $(3 \%)$ of silicate mineral in diets is more effective than the lower level (1.5\%) in improving tibia bone characteristics and ash in broiler chickens.
\end{abstract}

KEY WORDS: silicate mineral, ash, tibia morphometric, calcium, phosphorus, broiler

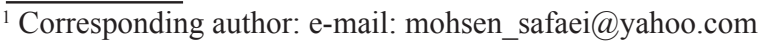




\section{INTRODUCTION}

Kaolin or china clay is a mixture of different minerals. Its main component is kaolinite; but in addition, it contains quartz, mica, feldspar, illite, and montmorillonite. Kaolinite is made up of tiny sheets of triclinic crystals with pseudohexagonal morphology. It is formed by rock weathering and it has some cation exchange capacity (Adamis et al., 2005). The structure of kaolinite is a tetrahedral silica sheet alternating with an octahedral alumina sheet. These sheets are arranged so that the tips of the silica tetrahedrons and the adjacent layers of the octahedral sheet form a common layer (Trckova et al., 2004; Adamis et al., 2005). Bentonite is an expanding lattice clay of the montmorillonite group of minerals with high ion exchange capacity that binds a wide range of cations. Variations in interstitial water and exchangeable cations in the interlayer space affect the properties of bentonite and thus the commercial uses of the different types of bentonite (Adamis et al., 2005). Zeolites are crystalline, hydrated aluminosilicates of alkali and alkaline earth cations that possess three-dimensional structures with interconnecting channels and large pores, capable of trapping molecules of proper dimensions (Mumpton, 1999). The pore size in commercially available zeolite ranges from approximately $0.3-0.8 \mathrm{~nm}$. Clinoptilolite is the most widely used natural zeolite in animal studies due to its structural stability under high temperatures and acidic conditions (Tiwari, 2007).

Various researchers found that adding silicate mineral to broiler diets improved body weight gain and feed conversion ratio (Hesham et al., 2004; Prvulovic et al., 2008; Shi et al., 2009). Eliot and Edwards (1991b) declared that the reason for increasing the weight gain of broilers fed with zeolite was due to $\mathrm{pH}$ changes in the gastrointestinal tract. They also reported that in the presence of zeolite and when the $\mathrm{pH}$ reaches 6 in the gut, absorption of some nutrients and cations increases and this may improve weight gain. Leach et al. (1990) reported that the use of zeolite in diets increases the consumption of calcium and, in turn, increases the growth rate. So adding zeolite to diets containing the required amount of calcium is useful. Some studies show that broiler diets supplemented with silicate minerals increased calcium absorption and medullary bone development, but decreased phosphorus utilization (Watkins and Southern, 1992; Yalcin et al., 1995). Among many properties attributed to zeolites, two most characteristic ones that relate to their effectiveness in poultry nutrition are their ability to lose and gain water reversibly and to selectively exchange a variety of cations without major changes of structure.

The objectives of this study are to evaluate the effects of different levels of kaolin, bentonite, and zeolite on broiler performance, tibia, faecal and meat ash content, morphometric properties of the tibia, blood and tibia calcium and phosphorous. 


\section{MATERIAL AND METHODS}

\section{Experimental design and diets}

Four hundred and forty eight one-day-old male Ross-308 type broiler chicks were obtained from a commercial hatchery. Individually weighed chicks (43 $\mathrm{g}$ average initial liveweight) were divided at random into seven groups; each group was further divided into four replicate subgroups with 16 chickens. The experiment was carried out in a completely randomized design. Room temperature was maintained at $32^{\circ} \mathrm{C}$ for the first week and then gradually reduced to $18^{\circ} \mathrm{C}$ at the rate of $3^{\circ} \mathrm{C}$ per week. Light was provided $24 \mathrm{~h}$ continuously with overhead incandescent lighting by 10 lux during the 6-wk period of the experiment. Mineral analysis was done by combination of determining the chemical composition using $\mathrm{X}$-ray fluorescence spectrometry (XRF) and identifying or quantifying the oxide components using an X-ray diffraction (XRD) method. The chemical composition of kaolin, bentonite and zeolite is presented in Table 1 .

Table 1. Chemical composition of kaolin, bentonite and zeolite, $\%$

\begin{tabular}{lccc}
\hline Ingredients & Kaolin & Bentonite & Zeolite \\
\hline $\mathrm{SiO}_{2}$ & 67 & 66.59 & 66 \\
$\mathrm{Al}_{2} \mathrm{O}$ & 20 & 11.21 & 11.43 \\
$\mathrm{Fe}_{2} \mathrm{O}_{3}$ & 0.2 & 1.84 & 1.3 \\
$\mathrm{CaO}$ & 0.2 & 0.19 & 3.11 \\
$\mathrm{MgO}$ & 0.4 & 2.49 & 0.72 \\
$\mathrm{Na}$ & $\mathrm{O}$ & 2.50 & 2.01 \\
$\mathrm{~K}_{2} \mathrm{O}$ & 0.5 & 0.82 & 3.12 \\
$\mathrm{SO}_{3}$ & 0.7 & - & - \\
$\mathrm{TiO}_{2}$ & 0.01 & 0.02 & 0.21 \\
$\mathrm{L.O}^{1}$ & - & 14.28 & 12.05 \\
$\mathrm{S.I}^{2}$ & 10.90 & 28 & 35 \\
\hline
\end{tabular}

${ }^{1}$ loss on ignition; ${ }^{2}$ swell index

The evaluated diets were: 1 . control, 2. containing 1.5\% kaolin, 3. 3\% kaolin, 4. $1.5 \%$ bentonite, $5.3 \%$ bentonite, $6.1 .5 \%$ zeolite, and 7 . diet $3 \%$ zeolite. The experimental diets contained mostly maize and soyabean meal; during the starter period they included $20.85 \%$ crude protein (CP), $2900 \mathrm{kcal} \mathrm{ME} / \mathrm{kg}, 0.91 \%$ calcium, and $0.41 \%$ available phosphorus and were fed to broilers up to 21 days. The grower diets included $18.75 \% \mathrm{CP}, 3000 \mathrm{kcal} \mathrm{ME} / \mathrm{kg}, 0.84 \%$ calcium, and $0.33 \%$ available phosphorus were fed to broilers up to 42 days (Table 2). All of the diets during the starter and grower periods were isonitrogenic and isocaloric. The chickens were allowed access to the diets and water ad libitum. 


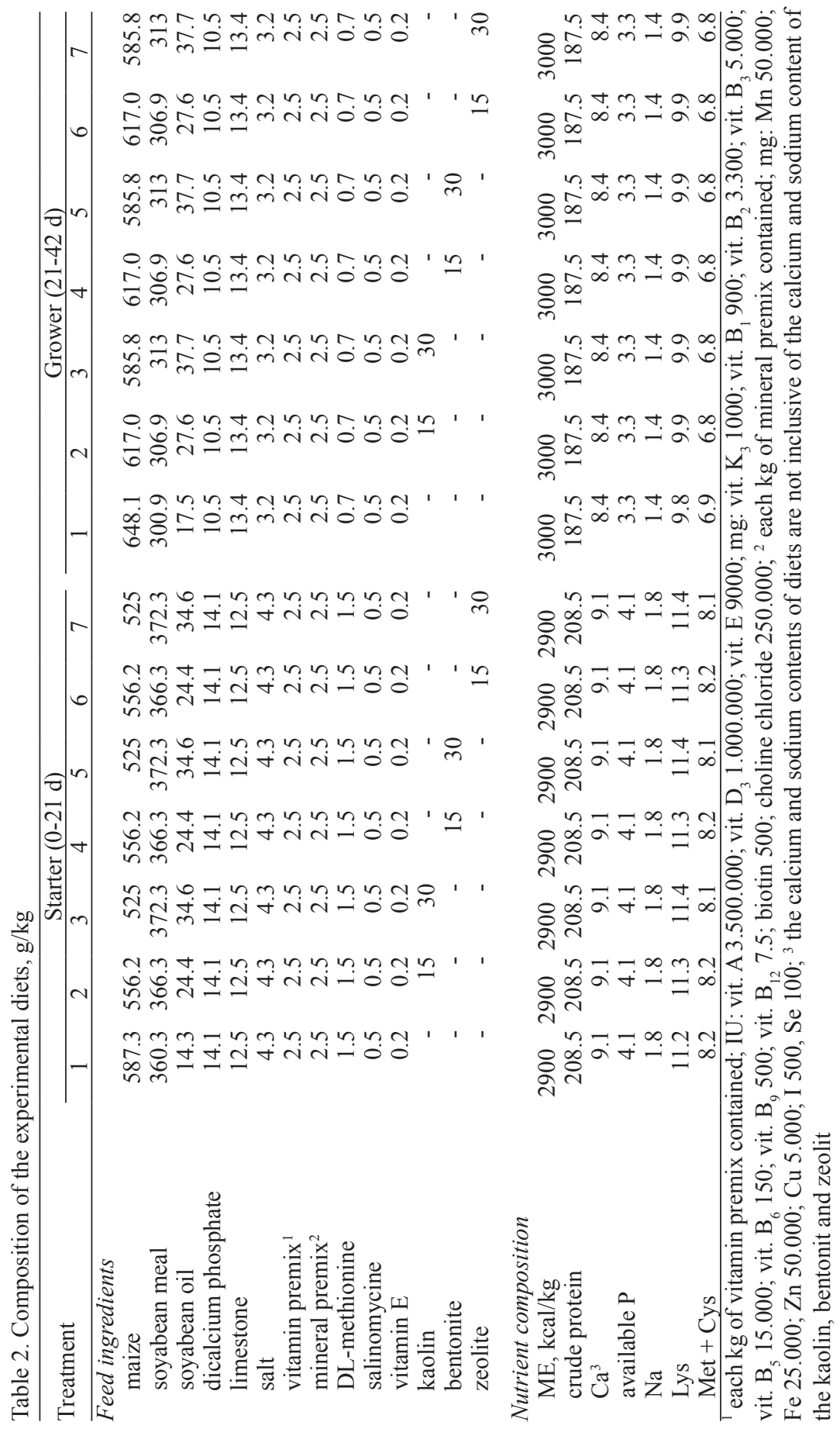




\section{Collection and analysis of samples}

At termination of the experiment, two birds from each pen were randomly selected, their body weights were determined, and slaughtered by cutting the carotid arteries and $2 \mathrm{ml}$ of blood sample were collected and stored at $-20^{\circ} \mathrm{C}$ until analysed. Also, the left tibias were removed from individual broilers and frozen. The tibias were later thawed and stripped of soft tissues. The tibiotarsal length was measured with a dial caliper and the bones were weighed on a precision balance. Following morphometric measurements and prior to breaking, each bone was marked at the midpoint and external diameters were measured. The thickness of the walls was measured as close as possible to the midpoint mark using a dial caliper. Medullary canal diameter was calculated by subtracting the thicknesses of the wall from the diameter of the diaphysis. The bone weight/bone length index was obtained by dividing the tibia weight by its length (Seedor et al., 1991). The tibiotarsal index and the robusticity index were determined using the formulas:

Tibiotarsal index $=$ diaphysis diameter - medullary canal diameter/diaphysis diameter $\times 100$ Robusticity index = bone length/cube root of bone weight

Faecal samples were taken from the centre and mid-way between the centre and the four corners of each pen for dry matter and ash analysis on day 40 of the experiment. The percentages of tibia, faecal and meat dry mater, ash and tibia calcium and phosphorus were determined according to AOAC (2005) methods. Plasma was separated by centrifugation of blood for $20 \mathrm{~min}$ at $3000 \mathrm{rpm}$ and saved for plasma calcium and phosphorus determinations. Plasma samples were processed by a Metrolab model 2300 plus autoanalyzer.

\section{Statistical analysis}

The data from all of the determinations were subjected to analysis of variance using the General Linear Models procedures of SAS (2003). Treatment means were ranked by Duncan's multiple range test. Differences were considered to be significant at the $5 \%$ level of probability.

\section{RESULTS}

The effects of kaolin, bentonite, and zeolite on performance are shown in Table 3 . Body weight gain was significantly $(\mathrm{P}<0.05)$ increased in treatments with $3 \%$ kaolin and two levels of zeolite (1.5 and 3\%) compared with $1.5 \%$ bentonite 
and the control. Feed intake was significantly $(\mathrm{P}<0.05)$ higher in chickens fed the diet containing 3\% bentonite than in chickens fed diets with $1.5 \%$ bentonite, $3 \%$ kaolin, or control. The feed conversion ratio was significantly better $(\mathrm{P}<0.05)$ in chickens fed 3\% kaolin when compared with those fed the control diet and that with $3 \%$ bentonite.

Table 3. Effect of kaolin, bentonite and zeolite on weight gain, feed intake and feed conversion ratio (FCR)

\begin{tabular}{lccc}
\hline Treatment & $\begin{array}{c}\text { Weight gain } \\
\text { g/day }\end{array}$ & $\begin{array}{c}\text { Feed intake } \\
\text { g/day }\end{array}$ & $\begin{array}{c}\text { FCR } \\
\text { g/g }\end{array}$ \\
\hline Control & $49.22^{\mathrm{b}}$ & $98.06^{\mathrm{b}}$ & $1.99^{\mathrm{a}}$ \\
Kaolin $1.5 \%$ & $52.01^{\mathrm{ab}}$ & $100.68^{\mathrm{ab}}$ & $1.93^{\mathrm{ab}}$ \\
Kaolin $3 \%$ & $52.33^{\mathrm{a}}$ & $97.78^{\mathrm{b}}$ & $1.87^{\mathrm{b}}$ \\
Bentonite $1.5 \%$ & $49.40^{\mathrm{b}}$ & $97.48^{\mathrm{b}}$ & $1.98^{\mathrm{ab}}$ \\
Bentonite $3 \%$ & $51.96^{\mathrm{ab}}$ & $104.56^{\mathrm{a}}$ & $2.01^{\mathrm{a}}$ \\
Zeolite $1.5 \%$ & $52.52^{\mathrm{a}}$ & $103.71^{\mathrm{ab}}$ & $1.98^{\mathrm{ab}}$ \\
Zeolite $3 \%$ & $52.74^{\mathrm{a}}$ & $100.74^{\mathrm{ab}}$ & $1.91^{\mathrm{ab}}$ \\
SEM & 0.89 & 1.99 & 0.03 \\
\hline
\end{tabular}

means within columns with no common superscripts are significantly different $(\mathrm{P}<0.05)$

Thickness of the wall in treatments with 3\% kaolin and bentonite and treatments with two levels of zeolite (1.5 and 3\%) increased significantly compared with the control $(\mathrm{P}<0.05)$. Treatments containing $3 \%$ bentonite and zeolite significantly improved the tibiotarsal wt/length, robusticity and tibiotarsal indices $(\mathrm{P}<0.05)$ when compared with the control. There were no significant $(\mathrm{P}>0.05)$ differences in tibia length, diaphysis diameter, medullary canal diameter, or relative bone weight among dietary treatments and control (Table 4).

The effect of dietary treatments on tibia, meat and faecal dry mater, and ash are given in Table 5. The tibia ash content increased significantly in the

Table 4. Effect of kaolin, bentonite and zeolite on tibia morphometric

\begin{tabular}{|c|c|c|c|c|c|c|c|c|}
\hline Treatment & $\begin{array}{c}\text { Length, } \\
\mathrm{cm}\end{array}$ & $\begin{array}{c}\text { Diaphysis } \\
\text { diameter, } \\
\mathrm{mm}\end{array}$ & $\begin{array}{c}\text { Thickness } \\
\text { of the wall, } \\
\text { mm }\end{array}$ & $\begin{array}{c}\text { Medullary } \\
\text { canal } \\
\text { diameter, } \\
\text { mm }\end{array}$ & $\begin{array}{c}\text { Relative } \\
\text { bone } \\
\text { weight, g }\end{array}$ & $\begin{array}{c}\text { Tibiotarsi } \\
\text { wt/length } \\
\text { index, mg/ } \\
\mathrm{mm}\end{array}$ & $\begin{array}{l}\text { Robusticity } \\
\text { index }\end{array}$ & $\begin{array}{c}\text { Tibiotarsal } \\
\text { index }\end{array}$ \\
\hline Control & 9.49 & 870 & $359^{\mathrm{b}}$ & 5.20 & 0.00504 & $64.41^{\mathrm{b}}$ & $4.19^{\mathrm{a}}$ & $40.83^{\mathrm{b}}$ \\
\hline Kaolin $1.5 \%$ & 9.62 & 8.97 & ab & 5.12 & 0.00504 & $66.42^{\mathrm{ab}}$ & $3.72^{\mathrm{ab}}$ & $42.89^{\mathrm{ab}}$ \\
\hline Kaolin 3\% & 9.75 & 9.15 & $4.02^{\mathrm{a}}$ & 5.13 & 0.00522 & $68.98^{\mathrm{ab}}$ & $3.25^{\mathrm{ab}}$ & $44.12^{\mathrm{ab}}$ \\
\hline Bentonite $1.5 \%$ & 9.66 & 9.07 & $3.92^{\mathrm{ab}}$ & 5.15 & 0.00505 & $66.80^{\mathrm{ab}}$ & $3.67^{\mathrm{ab}}$ & $43.40^{\mathrm{ab}}$ \\
\hline Bentonite $3 \%$ & 9.72 & 9.12 & $4.09^{\mathrm{a}}$ & 5.04 & 0.00515 & $69.61^{\mathrm{a}}$ & $3.14^{b}$ & $44.86^{\mathrm{a}}$ \\
\hline Zeolite $1.5 \%$ & 9.59 & 9.10 & 4 & 5.10 & 0.0 & 69. & $3.33^{\mathrm{ab}}$ & $43.96^{\mathrm{ab}}$ \\
\hline Zeolite 3 & 9.74 & & 4.1 & 5. & & & $3.10^{\mathrm{b}}$ & $45.07^{\mathrm{a}}$ \\
\hline SEM & 0.12 & 0.24 & 0.12 & 0.20 & 0.00015 & 1.53 & 0.29 & 1.18 \\
\hline
\end{tabular}
means within columns with no common superscripts are significantly different $(\mathrm{P}<0.05)$ 
Table 5. Effect of kaolin, bentonite and zeolite on tibia, meat and faecal dray mater and ash

\begin{tabular}{|c|c|c|c|c|c|c|}
\hline \multirow{2}{*}{ Treatment } & \multicolumn{2}{|c|}{ Tibia } & \multicolumn{2}{|c|}{ Meat } & \multicolumn{2}{|c|}{ Faecal } \\
\hline & DM & Ash & DM & Ash & DM & Ash \\
\hline Control & 47.74 & $42.11^{b}$ & 26.60 & $0.99^{\mathrm{b}}$ & $20.86^{\mathrm{c}}$ & $4.44^{\mathrm{a}}$ \\
\hline Kaolin $1.5 \%$ & 48.46 & $42.89^{\mathrm{ab}}$ & 25.03 & $1.04^{\mathrm{ab}}$ & $26.92^{\mathrm{a}}$ & $4.28^{\mathrm{ab}}$ \\
\hline Kaolin 3\% & 49.05 & $44.26^{\mathrm{ab}}$ & 24.82 & $1.16^{\mathrm{ab}}$ & $24.72^{\mathrm{abc}}$ & $3.83^{\mathrm{ab}}$ \\
\hline Bentonite $1.5 \%$ & 45.56 & $43.09^{\mathrm{ab}}$ & 26.09 & $0.97^{\mathrm{b}}$ & $21.47^{\mathrm{bc}}$ & $4.16^{\mathrm{ab}}$ \\
\hline Bentonite $3 \%$ & 46.09 & $45.15^{\mathrm{ab}}$ & 25.76 & $1.09^{\mathrm{ab}}$ & $26.99^{a}$ & $3.44^{\mathrm{ab}}$ \\
\hline Zeolite $1.5 \%$ & 48.46 & $45.01^{\mathrm{ab}}$ & 25.71 & $1.06^{\mathrm{ab}}$ & $24.36^{\mathrm{abc}}$ & $3.66^{\mathrm{ab}}$ \\
\hline Zeolite 3\% & 49.98 & $45.75^{\mathrm{a}}$ & 25.12 & $1.20^{\mathrm{a}}$ & $26.46^{\mathrm{ab}}$ & $3.20^{\mathrm{b}}$ \\
\hline$\underline{\text { SEM }}$ & 1.51 & 1.05 & 1.15 & 0.06 & 1.65 & 0.35 \\
\hline
\end{tabular}

means within columns with no common superscripts are significantly different $(\mathrm{P}<0.05)$

treatment with $3 \%$ zeolite compared with the control $(\mathrm{P}<0.05)$. Also, the meat ash content in the treatment with $3 \%$ zeolite increased significantly compared with the treatments with $1.5 \%$ bentonite and control. There were no significant differences in tibia and meat dry mater among dietary treatments. Faecal dry mater content in treatments with $1.5 \%$ kaolin and $3 \%$ zeolite and bentonite increased significantly when compared with the control $(\mathrm{P}<0.05)$. Also, there were significant differences among treatments containing $1.5 \%$ kaolin and $3 \%$ zeolite with the treatment containing $1.5 \%$ zeolite $(\mathrm{P}<0.05)$. Faecal ash content in the treatment with $3 \%$ zeolite decreased significantly compared with the control $(\mathrm{P}<0.05)$.

The blood calcium level increased significantly $(\mathrm{P}<0.05)$ in the treatment containing 3\% zeolite when compared with the control. Also, the amount of tibia calcium in the $3 \%$ zeolite treatment increased when compared with treatments containing $1.5 \%$ bentonite and control $(\mathrm{P}<0.05)$. There were no significant $(\mathrm{P}>0.05)$ differences in blood and tibia phosphorus among experimental treatments (Table 6).

Table 6. Effect of kaolin, bentonite and zeolite on blood and tibia calcium and phosphorous

\begin{tabular}{|c|c|c|c|c|}
\hline \multirow{2}{*}{ Treatment } & \multicolumn{2}{|c|}{ Blood, mg / $\mathrm{dl}^{-1}$} & \multicolumn{2}{|c|}{ Tibia, \% } \\
\hline & calcium & phosphorous & calcium & phosphorous \\
\hline Control & $8.21^{\mathrm{b}}$ & 4.27 & $22.28^{\mathrm{b}}$ & 11.45 \\
\hline Kaolin $1.5 \%$ & $8.34^{\mathrm{ab}}$ & 4.96 & $23.42^{\mathrm{ab}}$ & 11.84 \\
\hline Kaolin 3\% & $8.77^{\mathrm{ab}}$ & 4.44 & $24.19^{\mathrm{ab}}$ & 11.48 \\
\hline Bentonite $1.5 \%$ & $8.39^{\mathrm{ab}}$ & 4.91 & $22.33^{\mathrm{b}}$ & 11.91 \\
\hline Bentonite $3 \%$ & $9.04^{\mathrm{ab}}$ & 4.86 & $24.04^{\mathrm{ab}}$ & 11.62 \\
\hline Zeolite $1.5 \%$ & $8.90^{\mathrm{ab}}$ & 4.40 & $24.08^{\mathrm{ab}}$ & 11.60 \\
\hline Zeolite 3\% & $9.37^{\mathrm{a}}$ & 4.82 & $24.98^{\mathrm{a}}$ & 11.77 \\
\hline SEM & 0.34 & 0.30 & 0.75 & 0.43 \\
\hline
\end{tabular}

means within columns with no common superscripts are significantly different $(\mathrm{P}<0.05)$ 


\section{DISCUSSION}

The present study demonstrates that inclusion of silicate minerals in diets of broiler chickens improves weight gain and has no adverse effects on feed intake or feed conversion ratio (Table 2). The reason for this improvement may be the action of silicate minerals enhancing the digestibility of certain nutrients. Through temporary binding with nutrients, silicate minerals reduce the gastrointestinal passage rate, thus lengthening the time nutrients undergo digestion. Some studies show that the use of silicate minerals in broiler chicken diets improves their performance (Hesham et al., 2004; Prvulovic et al., 2008; Shi et al., 2009). Leach et al. (1990) reported that the use of zeolite in diets increases the consumption of calcium, which, in turn, increases the growth rate. Addition of zeolite to the diets containing enough calcium is beneficial. Eliot and Edwards (1991b) declared that the reason for the increase in the weight gain of broilers fed zeolite was the change in the $\mathrm{pH}$ of the gastrointestinal tract. They also reported that in the presence of zeolite when the gut $\mathrm{pH}$ reaches 6 , absorption of some feed nutrients, including cations, increases and this improves weight gain. In contrast, Southern et al. (1994) and Cabuk et al. (2004) reported that the supplementation of silicate mineral to the diet had no effect on the feed conversion ratio. It is possible to relate the existing differences in different experimental results to the use of different types of silicate minerals in broiler diets, maybe due to the structure of the mineral and the metal oxide content. So good processing to reduce metal oxide content, as much as possible, will result in better effects.

In this experiment, addition of the higher (3\%) level of silicate mineral in diets was more effective than the lower (1.5\%) in improving tibia bone morphometric characteristics (Table 3). The bone weight/bone length index is a simple index of bone density and the higher the index, the denser the bone. In contrast, a low robusticity index indicates a strong bone structure. Also, a high value of the tibiotarsal index points to a high mineralization level of the bone. The tibiotarsal index in the treatments including silicate mineral was higher compared with the control treatment and the robusticity index in these treatments was lower when compared with the control. These results suggest that supplementing silicate mineral to diets increased the degree of mineralization and development of the bone. Kaolin, bentonite, and zeolite have not been reported to influence tibia morphometric parameters.

The results of tibia, meat, and faecal dry mater and ash characteristics show that tibia ash, meat ash, and faecal ash contents improved on the treatment with $3 \%$ zeolite compared with the control and that there were no significant differences in tibia and meat dry mater among dietary treatments. Faecal dry mater content in the treatment with $1.5 \%$ kaolin and 3\% zeolite and 3\% bentonite increased significantly $(\mathrm{P}<0.05)$ compared with the control (Table 4). These results are 
supported by previous research done by Yalcin et al. (1995). They reported that using sodium zeolite A in broiler diets, they could increase the tibia ash content, but this did not affect the incidence of tibial dyschondroplasia. Also, Eliot and Edwards (1991b) used synthetic zeolite in broiler diets and reported similar results. Tatar et al. (2008) reported that using zeolite in broiler diets resulted in a significant increase of tibia ash content compared with the control. Prvulovic et al. (2008) found that the significantly higher values for breast and drumstick meat ash content in broilers were due to supplemental hydrated aluminosilicate. Southern et al. (1994) reported that when diets deficient in macro- and microelements were used, the tibia ash content decreased. In contrast to our study, supplementation of diets with sodium bentonite and sodium aluminosilicate had no influence on this parameter. Moghadam et al. (2005) found that the use of zeolite in diets had no significant effects on tibia ash content and that with a decreasing calcium level in diets, it reduced the tibia ash content. The interaction between zeolite and calcium on tibia ash content was also significant.

Such findings would be expected in view of the important role of calcium and phosphorus in the formation of the skeletal system and body metabolism. Calcium affects bone structure, blood coagulation, adhesion of molecules, neural transmission, muscle contraction, cellular motility, differentiation and proliferation, hormonal secretion, and apoptosis. Phosphorus is a constituent of bone, nucleic acids, high-energy compounds, and phospholipids found in membranes. Deficiency of calcium or phosphorus will adversely affect these important processes that are all a part of growth (Onyango et al., 2003). Herzig et al. (2008) indicated that increasing zeolite in broiler diets will increase blood and bone calcium, decreasing, however, the amount of phosphorus. Their results proved that the long-term application of zeolite had a positive effect on the lodgement of $\mathrm{Ca}, \mathrm{P}$, and $\mathrm{Mg}$ in the eggshell and in bones. Elliot and Edwards (1991a) believed the characteristics of the cation exchange capacity of zeolite will increase the amount of serum calcium. Keshavarz (1991) indicated that an increase in the amount of blood calcium was due to the prolonged passing of feed containing enough calcium and phosphorus. In another study, Leach et al. (1990) reported that zeolite increased calcium absorption but decreased that of phosphorus in the gut, concluding that this calcium-increasing effect of zeolite was due to the increased level of serum calcium of birds fed a diet containing zeolite. In contrast to the above finding, Cabuk et al. (2004) indicated that supplementing the diet with zeolite reduced faecal dry matter and crude ash. Eraslan et al. (2005) observed that the amount of blood calcium and phosphorus in diets containing bentonite decreased when compared with control. 


\section{CONCLUSIONS}

The results obtained under the conditions of this experiment showed that the cation exchange property of silicate minerals can improve the morphometric properties of the tibia of broilers when they are fed silicate-mineral- supplemented diets. Also, the inclusion of a higher level (3\%) of silicate mineral in diets is more effective than a lower $(1.5 \%)$ level on the lodgement of calcium and phosphorus in the blood and bones, and it improved tibia bone characteristics. There is, however, a need for further studies to determine the effects of silicate mineral on bone development in broilers and the mode of action of silicate mineral on bone mineralization.

\section{REFERENCES}

Adamis Z., Fodor J., Williams R.B., 2005. Bentonite, Kaolin, and Selected Clay Minerals. World Health Organization, Geneva (Switzerland)

AOAC, 2005. Association of Official Analytical Chemists, Official Methods of Analysis. $18^{\text {th }}$ Edition. Gaithersburg, MA

Cabuk M., Alcicek A., Bozkurt M., Akkan S., 2004. Effect of yucca schidigera and natural zeolite on broiler performance. Int. J. Poultry Sci. 3, 651-654

Elliot M.A., Edwards H.M., 1991a. Comparison of the effects of synthetic and natural zeolite on laying hen and broiler chickens performance. Poultry Sci. 70, 2115-2130

Elliot M.A., Edwards H.M., 1991b. Some effects of dietary aluminum and silicon on broiler chickens. Poultry Sci. 70, 1390-1402

Eraslan G., Essiz D., Akdogan M., Sahindokuyucu F., Altintas L., 2005. The effects of aflatoxin and sodium bentonite combined and alone on some blood electrolyte levels in broiler chickes. Turk. J. Vet. Anim. Sci. 29, 601-605

Herzig I., Strakova E., Suchy P., 2008. Long-term application of clinoptilolite via the feed of layers and its impact on the chemical composition of long bones of pelvic limb (femur and tibiotarsus) and eggshell. Vet. Med. Czech 53, 550-554

Hesham M.T., Hegazy A.A., Hussein Y.A., 2004. Efficiency of kaolin and activated charcoal to reduce the toxicity of low level of aflatoxin in broilers. Sci. J. King Faisal Univ. 5, 145-159

Keshavarz K., 1991. The effect of calcium sulfate (gypsum) in combination with different sources and forms of calcium carbonate on acid base balance and egg shell quality. Poultry Sci. 70, 1723-1731

Leach R.H., Heinrichs B.S., Burdette J., 1990. Broiler chicks fed low calcium diets, Influence of zeolite on growth rate and parameters of bone metabolism. Poultry Sci. 69, 1534-1543

Moghadam H.N., Rezaei M., Abadi H., 2005. Effect of natural zeolite on performance, and tibia composition of broiler chicks. In: Proceedings of XVII European Symposium on the Quality of Poultry Meat and XI European Symposium on the Quality of Eggs and Egg Products. Doorwerth (The Netherlands), pp. 200-202

Mumpton F.A., 1999. La roca magica: uses of natural zeolites in agriculture and industry. Proc. Nat. Acad. Sci. USA 96, 3463-3470

Onyango E.M., Hester P.Y., Stroshine R., Adeola O., 2003. Bone densitometry as an indicator of percentage tibia ash in broiler chicks fed varying dietary calcium and phosphorus levels. Poultry Sci. 82, 1787-1791 
Prvulovic D., Kogic D., Lasic G.G., Kosarcic S., 2008. The effects of dietary inclusion of hydrated aluminosilicate on performance and biochemical parameters of broiler chickens. Turk. J. Vet. Anim. Sci. 32, 1-7

SAS, 2002-2003. SAS/STAT® User's Guide: Statistics, Version 9.1. SAS Institute Inc. Cary, NC

Seedor J.G., Quarruccio H.A., Thompson D.D., 1991. The bisphosphonate alendronate (MK-217) inhibits bone loss due to ovariectomy in rats. J. Bone Miner. Res. 6, 339-346

Shi Y., Xu Z., Sun Y., Wang C., Feng J., 2009. Effects of different types of montmorillonite on growth performance and serum profiles of broiler chicks during aflatoxicosis. Turk. J. Vet. Anim. Sci. 33, 15-20

Southern L.L., Ward T.L., Binder T.D., Hebert L.G., 1994. Effect of sodium bentonite or hydrated sodium calcium aluminosilicate on growth performance and tibia mineral concentrations in broiler chicks fed nutrient deficient diets. Poultry Sci. 73, 848-854

Tatar A., Boldaji F., Dastar B., Yaghobfar A., 2008. Comparison of different levels of zeolite on serum characteristics, gut $\mathrm{pH}$, apparent digestibility of crude protein and performance of broiler chickens. International Zeolite Conference. Tehran (Iran), p. 235

Tiwari J., 2007. Zeolite as natural feed additives to reduce environmental impacts of swine manure. M.Sc. Thesis, McGill University, Montreal (Canada), pp. 100

Trckova M., Matlova L., Dvorska L., Pavlik I., 2004. Kaolin, bentonite and zeolites as feed supplements for animals: health advantages and risks. Vet. Med. Czech 49, 389-399

Watkins K.L., Southern L.L., 1992. Effects of dietary sodium zeolite A and graded levels of calcium and phosphorus on growth, lama and tibia characteristics of chicks. Poultry Sci. 71, 1048-1058

Yalcin S., Bilgili S.F., Mcdaniel G.R., 1995. Sodium zeolite A: Influence on broiler carcass yields and tibia characteristics. J. Appl. Poultry Res. 4, 61-68 